\title{
Construction and Implementation of Network Teaching Platform for Western Music History and Masterpiece Appreciation Course
}

\author{
Jie Lin \\ Jiangxi Science \& Technology Normal University, Jiangxi Province, Nanchang, 330013
}

Keywords: Western Music History, Masterpiece Appreciation Course, Network Teaching Platform

\begin{abstract}
In recent years, the state has paid more and more attention to the education of colleges and universities, and the application of network data technology in high school curriculum has been more and more extensive. It has realized the combination of traditional teaching and network multimedia teaching. Western music history and masterpiece appreciation course network platform construction has gradually become the focus of attention of colleges and universities. The construction of the network teaching platform changes the traditional mode, and the networked teaching brings hope and opportunity to the teaching of western music history and famous teaching. How to use the network teaching platform in colleges and universities is the problem that the educators need to think about. This paper explores the concrete implementation method of constructing the network teaching platform of western music history and masterpiece appreciation course through the research on the construction of the network teaching platform of western music history and famous works appreciation, hoping to play a reference function.
\end{abstract}

\section{Introduction}

Traditional Western music history and masterpiece appreciation course using the "full house" teaching methods, students are difficult to improve their teaching through music appreciation ability. With the rise of the networked teaching platform, colleges and universities attach great importance to the reform of western music history and famous works, how colleges and universities should construct the western music history and masterpiece appreciation course, and combine the traditional face-to-face teaching mode with the networked teaching mode. The network teaching platform provides sufficient teaching resources for the teaching of western music history and famous works, so that the students 'western music history and masterpieces cannot be limited by time and space. This is undoubtedly a great improvement to improve students' ability of western music appreciation. This paper studies the construction of the network teaching platform of western music history and famous works, which is conducive to the teaching reform of western music history and masterpiece appreciation.

\section{The Construction Concept of Network Teaching Platform for Western Music History and Masterpiece Appreciation Course}

Western music history and masterpiece appreciation course network teaching platform to build, build the core content for the Western music works, to cultivate students' appreciation of the works of famous works of music, the Western music history masterpiece and the evolution of Western music style and Western music background to explain, thus enhance students' aesthetic ability of music. The network teaching platform must be clear the western music history and masterpiece appreciation course teaching content, western music history, music works analysis, western music background and so on to expand teaching. Therefore, the western music history and masterpiece appreciation course network teaching platform construction should follow the audio-visual resources to share, expand the teaching content and strengthen the teaching practice and other basic 
concepts [1].

Western music history and masterpiece appreciation course can use multimedia technology to teach, the western music history and masterpiece appreciation course audio-visual teaching and theoretical teaching combination, the use of network teaching platform to achieve Western music resources sharing. Western music history and masterpiece appreciation course teachers in the classroom teaching process should be good at using music pictures, music resources, network teaching resources. Network teaching platform resource library construction work is particularly important, the network database should include the teaching period of teaching resources and music resources, so that students can better use the network teaching platform to learn. Western music history and masterpiece appreciation course network teaching platform construction should not be confined to the Western music works, but also should be combined with the Western cultural background and the entire Western cultural process, so that students of Western music art a comprehensive understanding. Teachers display Western music materials and video information through the network teaching platform, all aspects of the students to improve the aesthetic ability. In addition, the western music history and masterpiece appreciation course how to combine theoretical courses and practice, but also to build the western music history and masterpiece appreciation course network teaching platform should think of factors. Therefore, the construction of the network teaching platform should be based on the concept, so as to provide effective training programs [2].

\section{The Construction Process History of Network Teaching Platform for Western Music History and Masterpiece Appreciation Course}

Build Network Teaching Team and Website. The construction Western music history and masterpiece appreciation course network teaching platform needs for professional teachers and network teaching website as a support. The construction of the network teaching platform should first ensure the teaching staff, the rational allocation of the teaching resources of the western music history, the effective teaching ability of the teachers in colleges and universities, and the combination of the scientific research work and the network teaching. The construction of the teaching resources of the website is also the most important. The choice of teaching resources should be based on the differences of professional characteristics to choose, follow the network teaching platform to build the basic concept, so as to expand the students' western music professional knowledge.

Create a Network Teaching Resources. Western music history and masterpiece appreciation course network teaching platform to build, we should first consider the network teaching platform resource library construction. Network resource library construction process should be teaching materials, teaching audio data, etc. combined. Western music history and masterpiece appreciation course network teaching platform construction should advance with the times, according to the needs of the development of the times for processing and integration of materials. Teachers in the teaching process through the network teaching platform to directly use the teaching resources, the different periods of Western music display, so as to improve students' ability to appreciate music and aesthetic ability.

Construct Network Teaching Platform Function Template. First of all, clear the teaching curriculum orientation, teaching methods, the choice of teaching content, teachers bear the obligation to upload teaching materials, class reference materials and test questions published in the class; secondly, the teaching of the course , the network teaching platform as a student to learn the main battlefield, students can learn according to their own progress and interest in selective learning, and through the online test questions online test; Finally, the construction of network teaching platform to strengthen the interaction between students and teachers to provide students with a platform for discussion and communication, students through the network teaching platform to share learning methods, so as to encourage more students into the study [3]. 


\section{The Application of Network Teaching Platform for Western Music History and Masterpiece Appreciation Course}

Achieve Network Teaching Resources Sharing. Traditional Western music history and masterpiece appreciation course teaching, there is a low class to the class and the situation of idle resources. This phenomenon is mainly due to two reasons, on the one hand, students for Western music history and masterpiece appreciation course lack of active learning motivation; the other hand, teachers lack the use of student network teaching resources. Western music history and masterpiece appreciation course network teaching platform in the construction, but also the need to build students and teachers teaching evaluation system, the proportion of student courses to score credits, increase the proportion of usual results, pay attention to the evaluation of teachers teaching feedback and students learning evaluation. Student evaluation system includes attendance, usually results assessment and final results assessment.

Achieve Online Platform Online Attendance. Western music history and masterpiece appreciation course network teaching platform build, but also on the students' online attendance. Teachers through the student website online time attendance, through the network teaching platform for post-homework, through the completion of student work and the submission time and the number of changes and then evaluate the student learning attitude. Teachers are according to the students in the usual homework scoring, students through the network teaching platform to check the usual results and ranking. Teachers use this evaluation method to effectively encourage students to learn.

Achieve the Organic Combination of Traditional Teaching and Network Teaching. The construction of the network teaching platform is the inevitable result of the social progress and the development of the network technology. The construction of the network teaching platform is the embodiment of the teaching idea and the teaching method of the university. Western music history and masterpiece appreciation course in order to improve the efficiency of teaching, we must build the history of Western music and masterpiece appreciation course network teaching platform. The network teaching platform should give full play to its function and value, establish a comprehensive network of online resource library, the traditional teaching methods and network teaching methods are organically combined to improve the western music history and masterpiece appreciation course teaching effect. College teachers not only use multimedia technology to use the network teaching resources, but also should actively guide students to use the network teaching platform after class, so that the western music history and masterpiece appreciation course network teaching platform to play its value [4].

\section{Conclusion}

Western music history and masterpiece appreciation course network teaching platform construction is undoubtedly the great progress of university teaching reform. The progress and development of the times means that the traditional way of western music teaching is no longer suited to the needs of social development. Music teaching in colleges and universities should attach importance to the combination of network teaching resources and traditional teaching, strengthen the construction of network teaching team and network teaching website, establish and improve the network teaching resource library, and construct the function template of multi - functional network teaching platform. Western music history and masterpiece appreciation course network teaching platform construction is a major change. The construction of the network teaching platform realizes the sharing of the network teaching resources, realizes the network platform to combine the students' online attendance, realizes the traditional teaching and the network teaching, and promotes the further development of the music teaching reform in colleges and universities. 


\section{References}

[1] Lin Rui, Chen Xiaoyu. On the public art curriculum education - "Western music appreciation" course teaching thinking [J]. Song Hai, 2008, 06: 96-97.

[2] Xu Jie. "Western music history and masterpiece appreciation" course of horizontal extension of teaching - to symphonic poem "Zarathustra said" appreciation as an example [J]. Art sea, 2011,09: 107- 108.

[3] Xu Jie. "Western music history and masterpiece appreciation" course of the horizontal expansion of teaching - to symphony "Faust" appreciation as an example [J]. Yellow River Voice, 2011, 15: 38-39.

[4] Chen Xin. Based on the wisdom tree MOOC platform of university public art course "Chinese and foreign architectural art appreciation" practice exploration [J]. The United States and the times (on), 2016, 09: 97-99. 